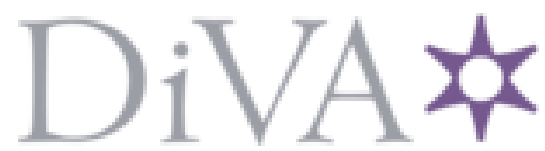

http://www.diva-portal.org

This is the published version of a paper presented at ICOLD Symposium, June 9-14, Ottawa, Canada, 2019.

Citation for the original published paper:

Nordström, E., Tornberg, R., Kamanga, R. (2019)

Management of ASR affected spillway structures at Kafue Gorge, Zambia In:

N.B. When citing this work, cite the original published paper.

Permanent link to this version:

http://urn.kb.se/resolve?urn=urn:nbn:se:kth:diva-260980 


\title{
Management of ASR affected spillway structures at Kafue Gorge, Zambia
}

\author{
E. Nordström \& R. Tornberg \\ SWECO, Stockholm, Sweden \\ R. Kamanga \\ ZESCO, Lusaka, Zambia
}

\begin{abstract}
The Kafue Gorge dam along Kafue River in Zambia was commissioned in 1971. In 1988 one of the spillway gates was jammed due to concrete expansion. Measures were taken, but signs of expansion and cracking continued. After rehabilitation works on one of the spillway gates in 2011 five stop-logs were stuck in position due to concrete expansion. In 2012, ZESCO and SWECO performed an in-depth assessment of the spillway structure with crack mapping and core sampling. Extensive cracking on the upstream side of the spillway piers with crack widths of up to $30 \mathrm{~mm}$ was found under water. Concrete analysis verified ongoing ASR. Numerical simulations on the behavior of the dam (with major cracks and ASR-expansion) showed that there was a need for stabilizing measures. SWECO designed remedial measures to restore full integrity of the dam and resolve the problem with the jammed stop-logs that caused reduced discharge capacity. During 2019 post-tensioned tendons are installed to ensure a monolithic behavior of the structure and improve the stability. All major cracks will be sealed to reduce the contact area of concrete and water. Finally, the jammed stop-logs will be removed to restore the discharge capacity of the spillway.
\end{abstract}

RÉSUMÉ: Le barrage de Kafue Gorge sur la rivière Kafue en Zambie a été mis en service en 1971. En 1988, une vanne de l'évacuateur de crue a été bloquée suite à l'expansion et à la fissuration du béton de la structure. Des actions correctives ont été mises en œuvre sans toutefois permettre d'arrêter le phénomène. En 2011, cinq batardeaux n'ont pu être retirés à l'issue de travaux de réparation réalisés sur une autre vanne de l'évacuateur à cause du même phénomène d'expansion. En 2012, ZESCO et SWECO ont réalisé une expertise de la structure de l'évacuateur avec notamment la cartographie des fissures poutrelles l'ouvrage ainsi que la prise d'échantillons par carottage. Ces investigations ont mis en évidence la présence d'une fissuration très développée sur la partie immergée de la face amont avec des ouvertures de fissure pouvant atteindre $30 \mathrm{~mm}$. L'analyse des échantillons de béton a mis en évidence un phénomène de réaction alcali-granulat (RAG). Des simulations numériques du comportement de la structure (incluant les principales fissures ainsi que l'expansion du béton causée par la RAG) ont mis en évidence la nécessité de conforter l'ouvrage. Les mesures correctives définies par SWECO seront mises en œuvre en 2019. Des tirants d'ancrage actifs seront installés afin de restaurer le comportement monolithique de l'ouvrage et d'en améliorer la stabilité. Les principales fissures seront comblées afin de réduire la surface de contact entre le béton et l'eau. Enfin, les poutrelles bloqués seront retirés, permettant ainsi à l'ouvrage de retrouver sa capacité d'évacuation nominale.

\section{BACKGROUND}

The spillway dam at Kafue Gorge along Kafue River in Zambia, owned by ZESCO was constructed between 1969 and 1971. The spillway dam height varies between $19 \mathrm{~m}$ (left hand) to 
$32 \mathrm{~m}$ (right hand) high and the length is $125 \mathrm{~m}$. The spillway dam consists of four radial discharge gates. To the right of the spillways there is a short buttress dam and further to the right there is an embankment dam. The left abutment consists of a solid gravity structure adjacent to the rock.

The spillway dam of Kafue Gorge has a long history with extensive concrete cracking and questions regarding the impact on dam safety arise. SWECO was appointed to perform an assessment of the status of the spillway dam and how to resolve the situation. In addition to the problems below, the fact that a number of stop-logs where jammed in spillway 1 was also dealt with as part of the project, but not described here.

\section{METHODOLOGY}

\subsection{ICOLD risk management}

Several bulletins within ICOLD gives guidance on dam safety management of existing facilities in general. Among them is the ICOLD bulletin no 154 (Hartford, D. \& al., 2017) on dam safety management with focus on the operational phase of the dam life cycle.

In a facility where observed deficiencies from a condition assessment are suspected to endanger the dam safety, further investigations and/or measures must be taken to reduce the risk. In analysis and selection of rehabilitation methods to eliminate threats or to reduce risks against reduced levels of dam safety, principles in the ICOLD bulletin 154 can be used. In principle the main task with the mission described in this paper has been to reduce the risk for dam safety problems and loss of production capacity at the Kafue Gorge facility due to the current cracking in the concrete spillway. In Figure 1, a risk level approach is illustrated (from Hartford \& al, 2017). The target risk level for the mission was developed in close cooperation between ZESCO and SWECO since the optimization of measures will be made taking risk, technical, economical and practical aspects into consideration. The target has been to reduce risks into the "Broad Acceptability Region".

\subsection{REHABCON-methodology}

A process to support the selection of repair measures for concrete structures has been developed within the European Union project entitled "Strategy for maintenance and rehabilitation of concrete structures" (REHABCON, 2004). REHABCON was preceded by another project, namely the CONTECVET (Concrete Vetting) (2001) project in which validated user's Manuals for the assessment of deteriorated concrete structures was developed. The



Figure 1. Levels of risk and the ALARP (As Low As Reasonably Practical) principle 


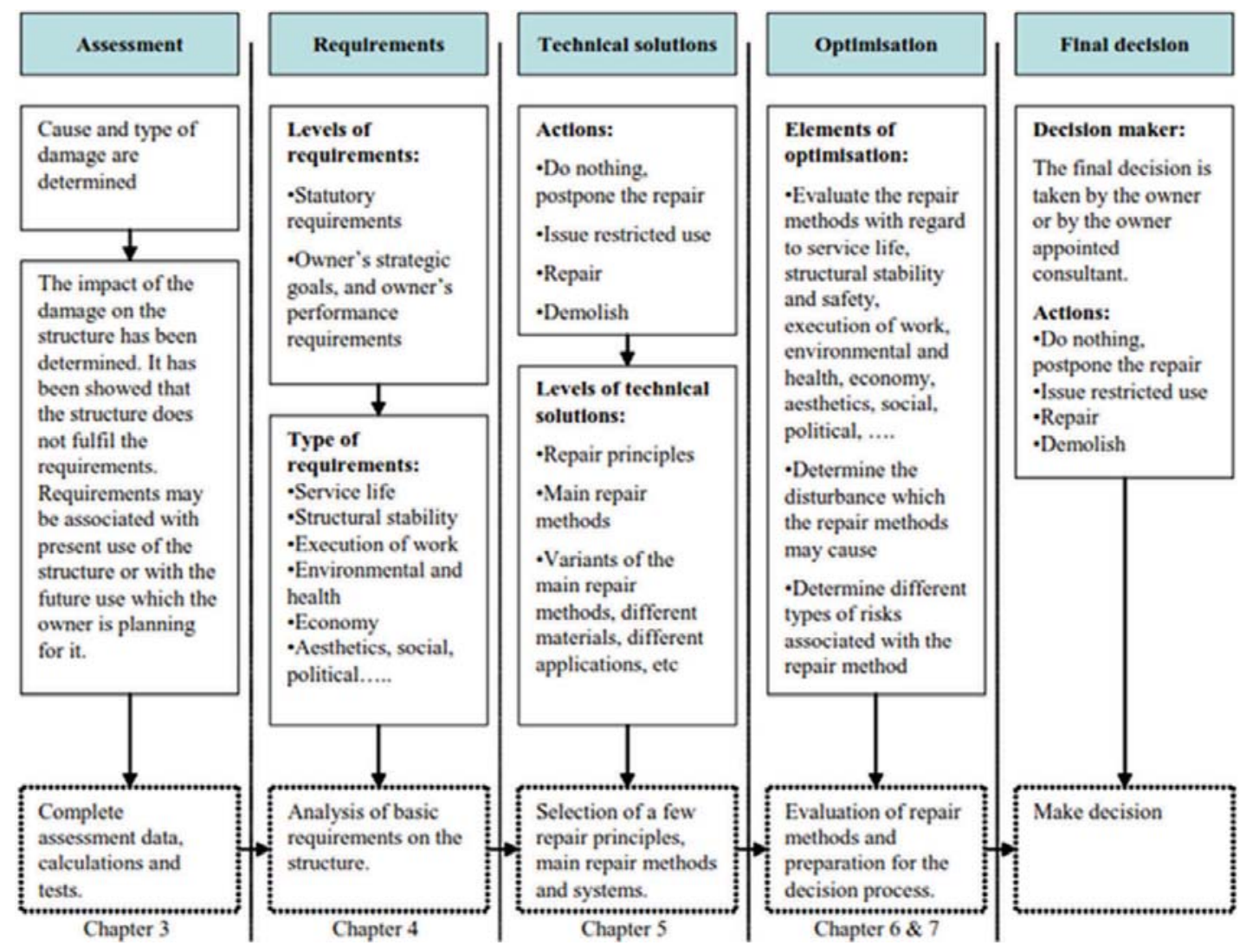

Figure 2. Repair process from REHABCON-manual (REHABCON, 2004)

CONTECVET manuals cover deterioration due to corrosion, frost action and alkali-silica reactions (ASR).

The objective of REHABCON was to provide a strategy for the repair and rehabilitation of the concrete infrastructure. The manual shows all recommended steps in the process to select a measure and in Figure 2 the schematic process is shown. The REHABCON repair process has been used for guidance and planning of the works.

\section{PROJECT ACTIVITIES}

\subsection{Assessment}

The assessment of a concrete structure should be based on the principle of progressive screening. This means that the investigation should be taken no further than is necessary to reach a decision, i.e. to decide which action is appropriate with an acceptable level of confidence. Thereby the assessment should, according to REHABCON be divided in:

- Preliminary Assessment (qualitative)

- Detailed Assessment (rigorous and quantitative)

Table 2 gives guidance in how the preliminary and detailed assessment in general for concrete structures can be divided according to REHABCON. The necessary input in Table 2 is targeted mainly at establishing the extent of the damage due to deterioration - and, of course, with identifying the primary cause of that damage. This involved a mix of "Overview" and "Insight" as illustrated in Figure 3. An overview will always be necessary; how much insight is required will depend on the nature and scale of the symptoms of deterioration. The further an assessment has to proceed, the more insight is necessary. The assessment within the project is presented in sections 4-7. 
Table 2. Schematic outline of progressive assessment procedures (REHABCON, 2004).

\begin{tabular}{|c|c|c|c|c|}
\hline \multirow{2}{*}{$\begin{array}{l}\text { Assessment } \\
\text { Phase }\end{array}$} & \multicolumn{3}{|l|}{ Conclusions } & \multirow[b]{2}{*}{ Recommendations } \\
\hline & Based on & Results & Reason & \\
\hline \multirow[t]{3}{*}{ Preliminary } & \multirow{3}{*}{$\begin{array}{l}\text { Records Survey data } \\
\text { Site measurement } \\
\text { Cores Crack pattern/ } \\
\text { width } \\
\text { Simple analysis }\end{array}$} & Adequate & $\begin{array}{l}\text { Sufficient residual } \\
\text { service-life and load- } \\
\text { bearing capacity. }\end{array}$ & Monitor \\
\hline & & Borderline & $\begin{array}{l}\text { Insufficient data or bearing } \\
\text { capacity marginally less than } \\
\text { required. }\end{array}$ & Detailed assessment \\
\hline & & $\begin{array}{l}\text { In- } \\
\text { adequate }\end{array}$ & $\begin{array}{l}\text { Insufficient residual } \\
\text { service-life and load- } \\
\text { bearing capacity. }\end{array}$ & $\begin{array}{l}\text { Modify adequacy } \\
\text { criteria and reassess. } \\
\text { Consider alternative } \\
\text { remedial actions. } \\
\text { Detailed assessment }\end{array}$ \\
\hline \multirow[t]{3}{*}{ Detailed } & \multirow{3}{*}{$\begin{array}{l}\text { Preliminary plus: } \\
\text { Monitoring } \\
\text { Laboratory tests } \\
\text { More sophisticated } \\
\text { analysis }\end{array}$} & Adequate & $\begin{array}{l}\text { Sufficient capacity } \\
\text { for required loading. }\end{array}$ & Monitor \\
\hline & & Borderline & $\begin{array}{l}\text { Insufficient data or } \\
\text { residual service-life and } \\
\text { load-bearing capacity margin- } \\
\text { ally less than required. }\end{array}$ & $\begin{array}{l}\text { Load test to classify } \\
\text { as adequate or in- } \\
\text { adequate. Consider } \\
\text { future management } \\
\text { and maintenance }\end{array}$ \\
\hline & & $\begin{array}{l}\text { In- } \\
\text { adequate }\end{array}$ & $\begin{array}{l}\text { Insufficient residual } \\
\text { service-life and load- } \\
\text { bearing capacity. }\end{array}$ & $\begin{array}{l}\text { Modify adequacy } \\
\text { criteria and reassess. } \\
\text { Consider alternative } \\
\text { remedial actions. } \\
\text { Detailed assessment }\end{array}$ \\
\hline
\end{tabular}

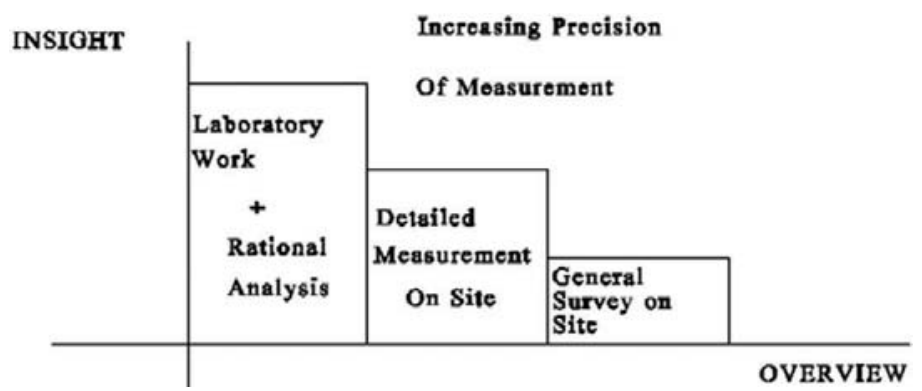

Figure 3. The essential balance between insight and overview in assessment (REHABCON, 2004).

\subsection{Requirements}

\subsubsection{General}

The requirements of the structure are fundamental for all decisions made and are strongly connected to the preceding assessment. These requirements may trigger further assessment and investigations. All existing technical and non-technical requirements and restrictions associated with the assets should be considered. The requirements concerning deteriorated and repaired structures are as follows according to REHABCON (2004):

- Service life

- Structural stability and safety

- Execution of work

- Economy

- Environment, aesthetics, social, political 


\subsubsection{Project specific}

The spillway structure should be able to provide a good serviceability with controlled discharge of water from the reservoir to avoid overtopping or uncontrolled discharge and safely store water in the reservoir with full stability of the water retaining structures.

To assure full discharge capacity in the spillway, the gates shall be able to operate safely without any risk of getting jammed in any position due to the concrete expansion. Jammed gates that will not open fully will decrease the discharge capacity and may lead to stability problems and overtopping of the adjacent embankment dam. In case a gate is jammed in an open position the reservoir water level will decrease drastically, resulting in loss of production in the crucial hydropower plant of Kafue Gorge with power shortage in the capital of Lusaka as a result.

Basically, the requirements on the concrete structures are that they must have sufficient stability, load-bearing capacity and be impervious for the entire service-life. The impact from the cracking must be estimated to ensure that the requirements are fulfilled now and for the future so that no further degradation could jeopardize the fulfilment of the requirements. The repair works should be designed for a service life of approximately 50-100 years.

\subsection{Technical solutions}

In the case when an assessment give that the requirements are not fulfilled, the need for measures arise. To resolve noticed problems there are most commonly a number of technical solutions to choose from. The different options suggested in the current project are found in section 8 of the paper. REHABCON (2004) divide the evaluation of different technical solutions in three different levels namely:

- Level 1: Approved solutions (experience from previously executed repair)

- Level 2: Qualitative evaluation (Level $1+$ semi-quantitative and/or qualitative reasoning by experienced engineer

- Level 3: Quantitative evaluation (Mainly service-life evaluation models)

\subsection{Optimization and decision}

When the cause of damage and type of damage are known, and the functional requirements of the repaired structure have been established, some alternative repair methods exist. For each method there are normally many repair materials (or processes) available. The solutions selected are evaluated in terms of how well they fulfil the requirements listed under section 3.2.1

Finally, the owner must decide, taking all the given input from studies into account.

\section{PRELIMINARY ASSESSMENT}

\subsection{Documents from the time of construction}

Specifications on the concrete was found in the contract documents where the use of ordinary Portland cements was specified (not low-alkali). The cements should fulfil the requirements of British standard 12:1958 and also:

"The cements should be tested together with fine and coarse aggregates, obtained from the actual borrow areas at the site, to determine alkali reactivity in accordance with ASTM Designation C 227 and shall not, within three months, show any harmful swelling."

A search in the archives did not show any reports on this type of testing.

\subsection{Interview with staff from the time of construction}

A contact with the retired former SWECO employee Mr. Fossgaard was established. Fossgaard (2014) worked with site control of concrete mixing at the time for construction. According to 
Fossgaard (2014) there were major problems with finding the proper amount of sand of acceptable quality and wordings like "sabotage and illegal sand transport were common" is used. This can have caused mistakes and a potential for delivery of uncontrolled material.

Fossgaard (2014) pointed out the risk for presence of montmorillonite (or smectite). Coarse material from the excavation of the tunnel was used to produce concrete aggregates. The tunnel material was reported to show some zones with content of montmorillonite (or smectite) and that this type of material was discarded as far as practically possible. Montmorillonite expands with access to water and for some types the swelling pressure that develops is high enough to crack both rock and concrete.

From the petrographic investigations presented in section 5.3 there are no signs of montmorillonite in the samples. The petrographic investigation also points on variations in the reactivity that might have its origin in the difficulties with the fine material sources in during construction.

\subsection{Levelling measurements}

To be able to follow the expansion of the concrete spillways, geodetical levelling measurements on the crest have been made for a period of ten years. Vertical crest movements in the range of 5-15 mm was reported, but there was also a large scatter and no correlation to the current reservoir level and the quality of the measurements was considered unreliable.

\subsection{Visual inspection, crack mapping and stop-log examination}

The site operation in December 2013 was supervised by SWECO. The crack mapping was conducted by NSE (Nuclear Structural Engineering) and the diving operation was conducted by Dive Worx both from South Africa and as sub-contractors of CITICON from Zambia.

\subsubsection{General}

The crack mapping was performed with divers under water and by NSE engineers on parts not submerged and in the inspection gallery. Parts of the structure were not accessible due to a damaged sealing on the left-hand side of gate 3. Horizontal parts upstream of the gate were covered with silt and therefore also not possible to inspect.

\subsubsection{Above water level}

Crack patterns are documented briefly on the piers, the base slab and very detailed in the galleries under the spillways. Generally, almost all surfaces on the piers show extensive mapcracking (see Figure 5 for examples) which is typically related to ASR expansion. The general crack width for this type of cracking is between 0.5 and $1.5 \mathrm{~mm}$. Close to the gate there are some more accentuated horizontal cracks. In the lower parts some of the cracks extend over the entire length of the piers occasionally bending downwards closer to the downstream end of the piers.

In the inspection gallery the crack patterns basically are horizontal on the face towards the upstream side. The parts of the piers visible in the gallery show cracks that are inclined upwards towards the downstream part. Crack widths can be up to several mm's. In Figure 4 the external surfaces of Pier 2 are shown. Horizontal surfaces, as the downstream spillway slab surfaces show, where inspectable, limited cracking and some cracks are probably more of the shrinkage type cracks.

\subsubsection{Mapping with divers}

The subsurface inspection of the upstream side was performed by three divers supplied with cameras and sound communication with the diving supervisor who also took notes on identified cracks. All the underwater inspections were recorded with video and sound. At the time of performing the diving operation the visibility in the water was very limited $(0.5-1.0 \mathrm{~m})$ due to high amounts of vegetation/algae in the water. At larger depths the helmet light therefore also was a bit weak and it became difficult to get a good overview of the surfaces. During the 


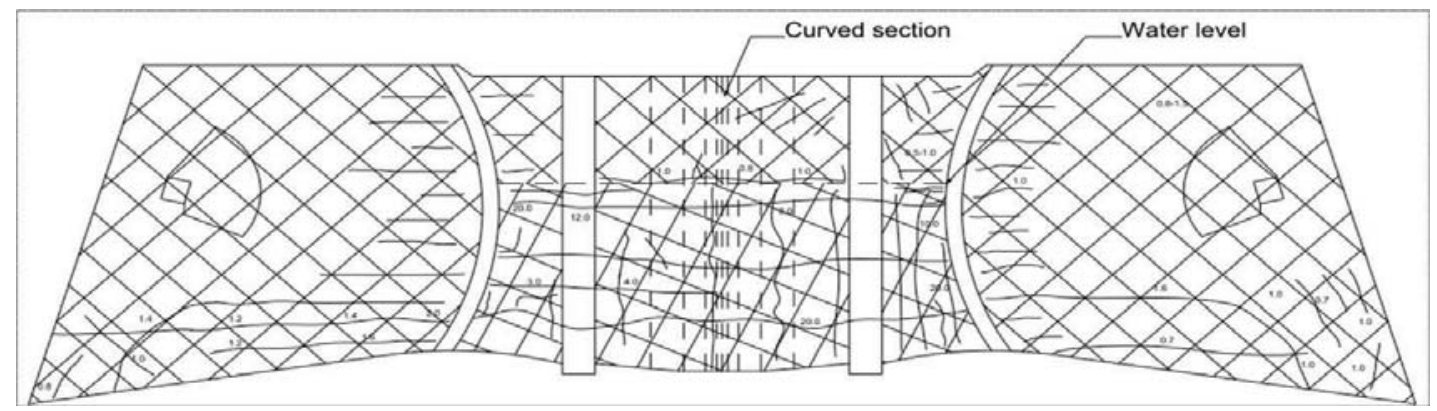

Figure 4. Crack patterns of Pier 2 (unfolded surfaces from upstream) (The hatch marks indicate general map-cracking).


Figure 5. Side of pier 4 (left) and top of pier 3 (right) with map cracking.

first dive for every diver there was some calibration to be made on what to measure and how. One crucial part in getting a very high quality of the crack mapping is to always know the position of the diver. This also became a challenge due to the limited visibility.

The results from the mapping very much goes in line with the results from the inspections above water level but the crack widths seem to be generally larger. There is general map cracking and some major cracks both horizontal and vertical. The largest subsurface cracks are major horizontal cracks on the piers at approximately level +971 masl. (meters above sea level) that coincides with a cold joint from the time of construction. The crack is visible on all piers and the width on pier 1 is in the range of $30 \mathrm{~mm}$ and the rest are in a span from $3-20 \mathrm{~mm}$.

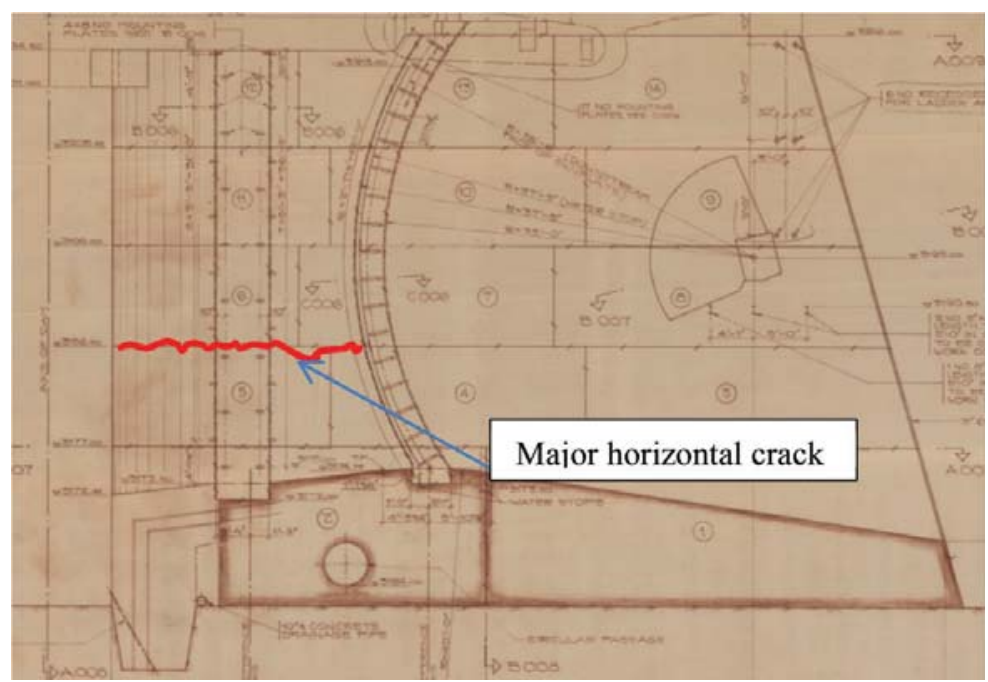

Figure 6. Elevation of Pier 2 and position of major crack indicated. 


\subsection{Concrete core drilling}

To define the current status of the concrete material in the spillway dam it was part of the joint mission to take concrete core samples from the dam. The goal was to find out general material composition, concrete strength properties and measure the remaining expansion potential. The purpose was to finally state the reason for expansion and to predict the future behavior and thereby estimate the potential dam safety risks and remaining service-life.

\subsubsection{Program for sampling}

Apart from the mix constituent's ASR is affected by the access to humidity and the load on the concrete. Higher access to humidity gives larger/faster expansion and larger confinement from overlying concrete limits the expansion. Therefore, these samples were taken from the lower parts of the piers on the downstream side where there is no continuous exposure to water (except from precipitation) and confinement from the overlying concrete in the pier. This would give a conservative result that can be interpreted as a reliable result on the safe side in the estimation of the remaining expansion potential.

The results from the crack mapping indicate a difference in expansion/cracking successively increasing to the left in the spillway. Samples were therefore taken both in pier no.1 and pier no.4. In addition to this, samples were also taken from the intake structure that also shows some indications on ongoing expansion.

\section{DETAILED ASSESSMENT - PART I}

\subsection{Compressive strength testing}

To find out the strength properties on the damaged concrete, samples for both compressive and tensile strengths test were taken. Compressive strength has been tested in a South African laboratory (Concrete Testing Services in Pretoria) basically according to the European method EN 12504-1:2009 and splitting strength according to EN 12390-6:2009. To see any effect of the difference in confinement, samples were taken both from the top of the piers and in the lower part.

The results of the concrete strength testing can be seen in Figure 7 and 8. The laboratory has made an adjustment for the number of voids and any visible reinforcement. The requirements according to the contract documents was $34,5 \mathrm{MPa}$ (5000 psi) after 28 days.

Generally, the results show a too low level in comparison to the design criteria's. A requested average level of more than $34.5 \mathrm{MPa}$ give that drilled out cores after 40 years of hydration was expected to show higher levels of compressive strength. Furthermore, the results from compressive strength tests show that the top of the piers generally have a lower strength. Commonly the lower parts of a large concrete structure reach a higher level due to better compaction. More remarkable is that the top levels of the concrete structures show a

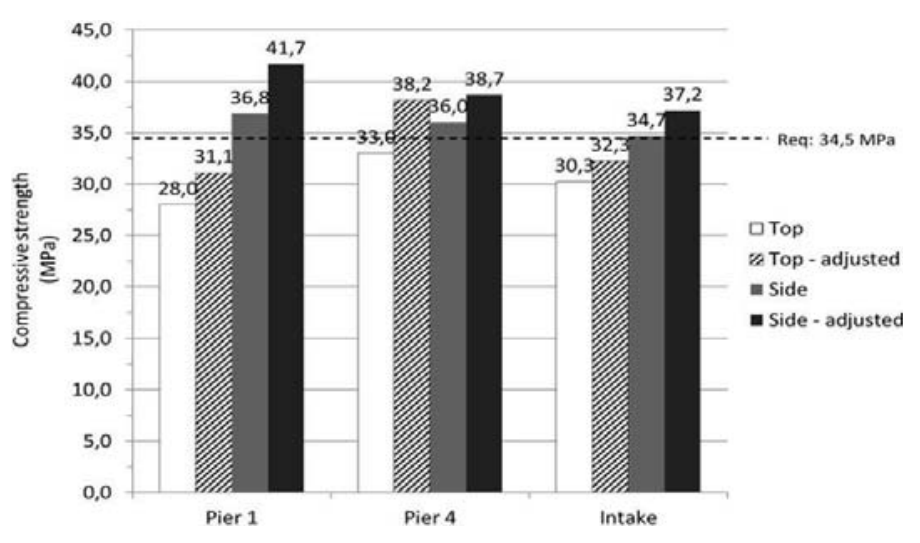

Figure 7. Compressive strength (average) according to EN 12504-1_2009 (150 mm cylinders, 1/h= 1). 


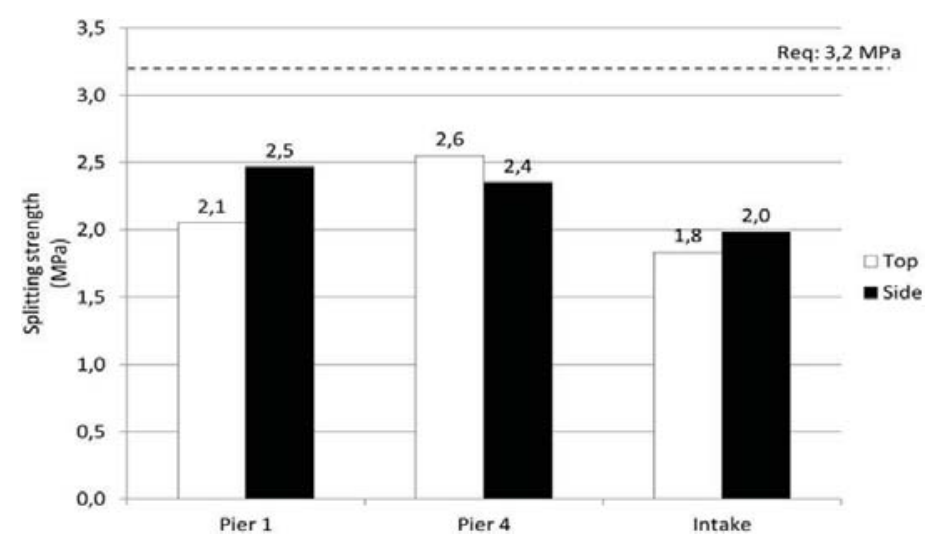

Figure 8. Splitting strength (average) according to EN 12390-6_2009 (150 mm cylinders, 1/h= 1).

strength level that is below the required value from the time of construction for the cores taken from the top. This is where the confinement is lower, and an ASR-expansion is more severe. The trend is that pier 1 shows lower values than pier 4 and the intake which also supports the visual impression of more severe ASR to the left in the spillway.

\subsection{Splitting strength testing}

Looking at the results for splitting strength the intake shows the lowest values. To keep in mind is that the standard deviation for samples from pier 1 was very large. Assuming a concrete quality of approximately C35/45 (compressive strength for cylinder/cube) cored samples should have reached higher levels of splitting strength. Using the equation (1) by Raphael (1984) below the expected splitting strength can be estimated to $3.2 \mathrm{MPa}$ when using a compressive strength of 34.5 MPa:

$$
f_{t}=0.3 \times\left(f_{c}\right)^{2 / 3}
$$

\subsection{Petrographic analysis}

To identify the type of aggregate used and to investigate if ASR is ongoing in the concrete a petrographic analysis on thin sections were made. Also, an estimation of the water-/cement ratio and the cement content has been made. In all samples ongoing ASR was verified. Cracks and air voids filled with ASR-gel are visible. The morphology of the cracks also indicates cracking after hardening of the concrete and not a result from early thermal action or plastic shrinkage.

In Figure 9 an example of cracks in aggregate can be seen. The investigated aggregate contains mainly of meta-sedimentary aggregates, quartzite and gneiss. The alkali reactive and potentially reactive aggregates contain brecciated gneiss, mylonite, low-metamorphic quartzite and sandstone. The content of alkali reactive and potentially reactive aggregates is $20-30 \%$ according to RILEM (2003), which is above the recommended $15 \%$ according to the standard SS-EN 137003 (2015). The general result of the amount of cracking due to ASR-gel in the samples is described as varying from "low to moderate micro crack frequency" to "high frequency". This might be interpreted as if there are variations in the aggregates used.

The water/cement ratio has been estimated to $0.35-0.45$ which seems a bit too low in comparison to the documentation from the time of construction that states a w/c- ratio of 0.5 . 


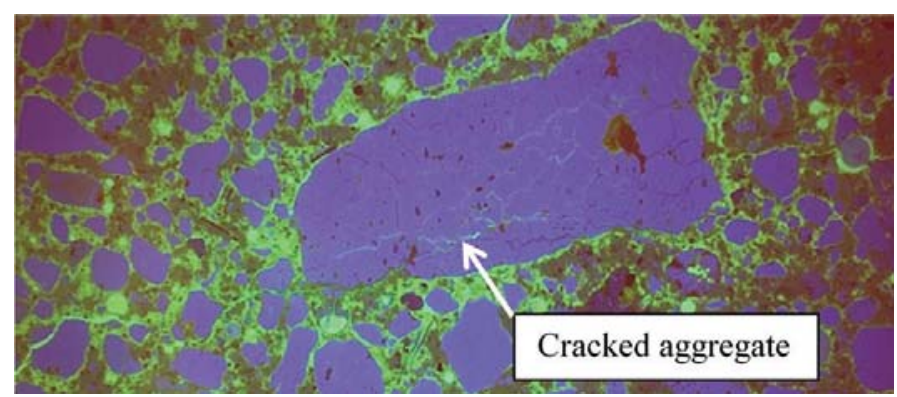

Figure 9. Thin sections of sample in UV-light.

\subsection{Chemical analysis of cement paste}

To verify the type of cement used, a chemical analysis of the cement paste was performed. The analysis was performed with scanning electron microscope and the analyses show that the cement is of low alkali type $\left(\mathrm{Na}_{2} \mathrm{O}_{\text {ekv }}=0.5\right)$. The limit for considering the cement as low alkaline is that the $\mathrm{Na}_{2} \mathrm{O}_{\text {ekv }}$ shall be below 0.6. Previously the belief that this would prevent an expansion when combined with reactive aggregate is today being questioned (Nordström, 2013). The formation of ASR-gel has occurred despite the use of low alkali cement.

\subsection{Cement content}

To be able to estimate the total alkali content of the concrete the actual cement content of the concrete was determined, and the analysis gave a span of 320 to $340 \mathrm{~kg} / \mathrm{m}^{3}$.

When combining the results from the cement analysis regarding the alkali content of the cement and the cement content (Table 4), the total amount of alkalis in the concrete can be estimated. With an alkali content of $0.5 \%$ in the cement and a cement content of $320-340 \mathrm{~kg} / \mathrm{m}^{3}$ the total alkali content will be in the range $1.6-1.7 \mathrm{~kg} / \mathrm{m}^{3}$. A commonly accepted rule of thumb is that the alkali content should be below $3 \mathrm{~kg} / \mathrm{m}^{3}$ to minimize the risk for ASR when using reactive or potentially reactive aggregates. In spite of the low total alkali content ASR is found in the samples, but this has probably given a dampening effect on the ASR-reaction.

\subsection{Residual expansion tests}

To estimate the remaining ASR expansion potential an accelerated expansion test on drilled out samples was performed. The method is based on the Nordtest (1985), method 295, but partly modified (larger sample size). Samples are exposed to saturated sodium chloride solution and an elevated temperature up to $50^{\circ} \mathrm{C}$ for 275 days. Any remaining ASR-expansion potential should give expansion of the sample. Generally, the expansion during the accelerated test was limited. The sample showing the highest total expansion gave 0.19 per mille of expansion. Generally, a total remaining expansion below 0.5 per mille is considered limited.

\section{EVALUATION OF PRELIMINARY AND DETAILED ASSESSMENT PART I}

Generally, cracking of the concrete structures was extensive and multiple signs of expansion both under and above water level was seen. The crack frequency was verified to be higher to the left of the spillway structure and the crack widths are larger on the upstream side with single horizontal major cracks coinciding with cold joints. The visual signs pointing in the ASR-direction was verified in the petrographic analyses where reactive aggregates and ASR-gel was identified in spite of the use of low-alkali cements and the low total content of alkali.

The major cracks were considered to give a potentially other type of stability failure mode apart from the intended design. There can be a risk for partial overturning or partial sliding of 


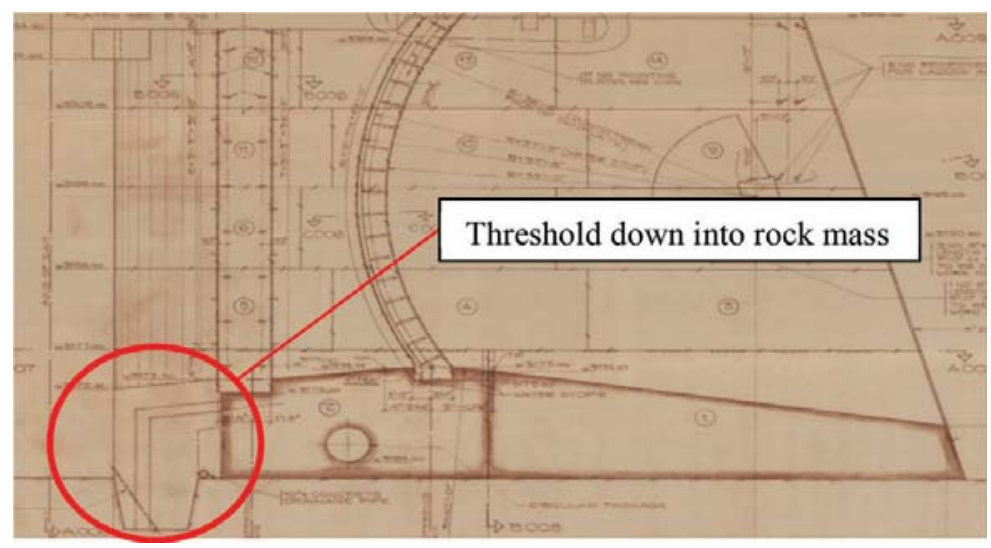

Figure 10. Section of spillway dam showing the threshold down into the rock mass.

the upper part of the piers. The reinforcement in the largest cracks was expected to have been broken and under high stress in parts where the crack width is still not that large. The cracks open for ingress of water causing additional uplift pressure on the part above the crack.

The remaining expansion potential was estimated to be limited. The generally limited expansion in the tests gives a suspicion that the major cracks on the upstream part of the piers also depends on something else.

The spillway was mainly designed as a gravity dam, but it also has an arch shape. The upstream threshold (see Figure 10) down into the rock gives a high restraint from movements in the horizontal direction. The arch shape makes any expansion within the dam or in the left abutment to cause vertical stresses on the upstream face of the spillway according to Penche (2004). The behavior is depending on the reason that the expansion pushes the spillway dam upstream, but in the bottom, it is prevented to move. This cause vertical stresses on the upstream side. The behavior in combination with the large horizontal cracks was recommended to be analyzed further.

To summarize the current dam safety status, it was considered that the extensive and partially large cracks were severe and irreversible. There is a risk that the vertical reinforcement is put under high tensile stresses and that any further expansion, water leakage and erosion will make the major cracks propagate further downstream. Apart from leakage the risk for future stability problems cannot be excluded. A temporary limitation of the retention level was recommended to be considered until further calculations or measures was taken.

\section{DETAILED ASSESSMENT - PART II}

With results from the preliminary and the first part of the detailed assessment it was decided to analyze the actual structural status. One of the prerequisites to be able to understand the dam behavior and to define the correct rehabilitation measure is the understanding of the original design of the concrete spillway. Review of intended structural way of action was part of this. The second part of the detailed assessment also focused on studying the impact from cracking on the structural behavior and stability of the dam and potential influence from the curved shape of the spillway dam.

Review of the geological investigations from the time of construction and any measures to reinforce the foundation and abutments was of major interest. The purpose was to look for any implications from the geological conditions in the left abutment and foundation that can be connected to the cracking and especially the fact that the cracking is more severe on the left part of the spillway dam.

In summary the second part of the detailed assessment contained: 
- Review of the original design and previous studies and measures on the concrete spillway and left abutment as input to the analysis of structural status.

- Analysis of structural behavior and stability taking into consideration the original design and current, cracked status.

- Comparison with the requirements on expected safety level according to international practice.

\subsection{Rock conditions}

Mapping the rock conditions in visual parts of the abutment and foundation area together with additional search in the archives from the time of construction was performed.

The dominating rock type close to the spillway dam consist of gneissic granite. Other rock types in the area are mica schist, dikes of amphibolite and veins of quartz. The rock mass quality of the gneissic granite was classified as fair to good, while the amphibolite and mica in some parts are decomposed and of poor rock quality. Especially the contacts between amphibolite and the host rock seem to be of poor quality. The investigations during the construction period show areas of amphibolite in the foundation. These structures in the foundation of the spillway may result in differential settlements of the spillway dam. However, these type of settlements is expected to influence the spillway structure mainly early after the time of construction.

In 2001 further investigations and stabilization measures were performed on Pier 1 and the left rock slope. The investigations presented, pointed out the possibility of a circular failure in the rock slope behind Pier 1. The measures included grouting, rock anchoring and drilling of drainage holes. The basis for the measures were the observed differential movement of Pier 1 and a judged risk for wedge failure in the rock slope based on geological investigations by core drilling. The grouting that was performed to reduce the hydraulic conductivity of the rock mass close to Pier 1 included 25 boreholes behind the pier. It is possible that the grouting may have caused some outward movements of Pier 1 on the upstream side below the installed line of horizontal rock anchors.

During the site visit and inspection of the rock slope the stability of the ground on the left side of the spillway appear to be satisfactory and no signs of larger slope instability were observed.

\subsection{Analysis of structural behavior}

The structural evaluation of the complete spillway including the threshold was done with an FE-analysis that considered both the effects of ASR, temperature expansion, rock movement and normal loads. The expansion from ASR is simulated as an additional temperature increase in the concrete. A brief overview of the FE-model is shown in Figure 11 below.

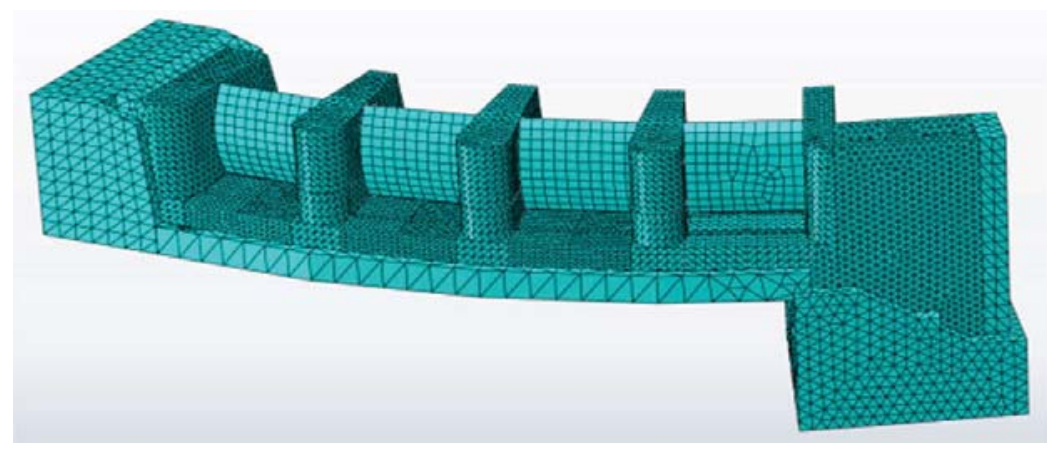

Figure 11. FE-model of the spillway dam. (Mesh, view from upstream). 
The results from the FE-analysis shows that a load case where the upstream side is exposed to an expansion due to ASR would lead to cracking like the observed one. The ASR is depending on access to water to be able to take place and thereby the upstream side probably expands more, making this a likely reason for the propagating major horizontal cracks. Some of the other cracks in the inspection gallery and just downstream the gate has probably also occurred due to ASR.

The same crack pattern was observed in the FE-analysis when the structure was exposed to high temperatures on the downstream side due to solar radiation and thereby heat (differential temperature between downstream side and the reservoir side). The stresses were not as high as in the load case with ASR but still shows the same behavior. In the FE-analysis minor cracks are also observed to be induced in the inspection gallery, just upstream the gate and on the downstream side below the trunnion. Thereby both the ASR and the thermal action on the concrete spillway give the crack patterns that can be seen on the actual spillway dam.

A normal load case and a scenario where the rock foundation on the left side is displaced to the right, does not show any stresses that could have led to the observed cracking.

Due to temperature cycles and the fact that the concrete could expand more due to ASR, a crack could propagate through the whole pier. It was recommended that a conservative approach with non-monolithic behavior should be used in the design of the reinforcement solution.

Existing reinforcement bars acts as extra safety, but it is hard to verify their contribution to resistance in the cracked section during a seismic event or a high load. Therefore, their contribution is not accounted for according to dam safety regulations. Some reinforcement bars could already have sheared off due to the expansion and corresponding large crack widths in some of the piers.

The global stability was analyzed analytically, and the results showed deficiencies when considering the risk for a non-monolithic failure and when seismic loads were applied. To fulfil the dam safety regulations regarding stability the piers and the crest dam needs structural reinforcement.

\subsection{Conclusion from the detailed assessment - part II}

In the comparison of results from the assessment, with the performance requirements, the major cracks in the spillway piers can lead to a failure especially during a seismic event. In terms of safety margin, it must be considered that the spillway dam falls short of the acceptable limit.

The current integrity and stability of the concrete spillway dam does not fulfil minimum acceptable levels and there is a need for measures to extend the service-life.

\section{TECHNICAL SOLUTIONS}

To resolve the issues listed in section 7 , different technical solutions were discussed together with ZESCO and the alternatives put on the table were:

- A0. No measures

- A1. Installing post-tensioned anchors

- A2. Overlay concrete with heavy reinforcement

- A3. Addition dead weight on crest

- A4. Replacement of heavily cracked piers with new concrete

The alternatives are briefly described below. 


\subsection{A0 - No measures}

Further expansion is expected to be limited due to ASR in the concrete, but movements in the left abutment giving squeezing of the spillway cannot be excluded. Cracks can continue to grow to some extent and water will continue to give uplift pressure. The risk for partial overturning or sliding of the upper part of the monolith followed by a dam breach must be considered. Leakage followed by leaching is another potential long-term consequence. In addition to these major dam safety problems also jamming of the gates can occur with a risk for overtopping and dam breach in a flood situation. The consequences from a dam breach can be loss of human lives, loss of energy production and major costs to rebuild the dam without being able to plan and design this in advance.

\subsection{A1 - Installing post-tensioned anchors}

To reduce the risk for a non-monolithic behavior installation of post tensioned anchors can be used. The repair operation is a standard method. The anchors are inspectable from the crest and can be tested after time to verify the function every 5-10 years. The post-tensioned anchors are preferably installed with an angle towards the upstream toe as in, giving a more ductile behavior of the tendon and better protection against a sliding failure. To ensure a service life of approximately 50 years for a repair option with post-tensioned anchors, the environment in which the tendons are installed must be good. There might be a risk for crossing cracks in concrete or rock with water pressure inside of the pier or foundation.

\subsection{A2 - Overlay concrete with heavy reinforcement}

Restores the upstream face of the pier with new concrete and installation of new and additional reinforcement. All cracks will be closed in the concrete that has been overlaid. Hydro jetting of the concrete surfaces both above and under water before installation of new/additional reinforced concrete. Most of the works are done by divers under water, resulting in time consuming repairs and that the final concrete quality is lower than if it would have been casted under dry conditions.

\subsection{A3 - Addition of extra dead weight}

To apply a stabilizing force additional weight could be placed on top of the piers. Due to lack of space for the placement since the bridge deck is crossing over the spillways it is not possible to install the large amount of weight needed without limiting the access.

\subsection{A4-Replacement of heavily cracked piers with new concrete.}

Demolishing two of the heavily cracked piers and replacing them with new concrete. The repair is complex since a steel caisson or coffer dam is needed to be able to do the works. During the repairs the existing bridge and the gate needs to be supported, which is a complex operation as well. With this method, the concrete will have a long service life.

\section{OPTIMIZATION AND DECISION}

The mission objective has been to ensure an acceptable safety level of the Kafue Gorge spillway dam. Taking economy, service-life and uncertainties in the amount of work needed for the different options the final recommendation is to restore full stability level of the concrete structures according to repair option A1 with installation of inclined post-tensioned anchors in the piers and the right-hand buttress dam. In combination with sealing of the major cracks on the upstream side this is expected to give at least a 50-year expansion of the service-life of 
Table 3. Summary of options for concrete repairs.

\begin{tabular}{|c|c|c|c|c|}
\hline Alternative & Advantages & $\begin{array}{l}\text { Disadvantages / } \\
\text { risks }\end{array}$ & $\begin{array}{l}\text { Service-life } \\
\text { (years) }\end{array}$ & $\begin{array}{l}\text { Cost } \\
\text { (kUSD) }\end{array}$ \\
\hline A0 & No cost & Degradation continues & 0 & 0 \\
\hline No measures & & Requirements not fulfilled & & \\
\hline A1 & Simple installation & Testing every 5-10 yrs & $\sim 50$ & 500 \\
\hline $\begin{array}{l}\text { Crack repair }+ \\
\text { Post-tensioned } \\
\text { anchors }\end{array}$ & $\begin{array}{l}\text { Standard method } \\
\text { Inspectable }\end{array}$ & $\begin{array}{l}\text { Potential water leakage via } \\
\text { cracks during installation. }\end{array}$ & & \\
\hline A2 & Good sealing & Time consuming works & $50-100$ & 1100 \\
\hline $\begin{array}{l}\text { Overlay concrete } \\
+ \text { heavy reinforce- ment }\end{array}$ & Long service-life & $\begin{array}{l}\text { Underwater works } \\
\text { Lower quality of under- } \\
\text { water concrete }\end{array}$ & & \\
\hline $\begin{array}{l}\text { A3 } \\
\text { Additional } \\
\text { dead weight }\end{array}$ & Cheap & Not enough space & - & - \\
\hline $\begin{array}{l}\text { A4 } \\
\text { Replacing two } \\
\text { piers }\end{array}$ & $\begin{array}{l}\text { New concrete } \\
\text { Long service-life }\end{array}$ & $\begin{array}{l}\text { Complex repairs } \\
\text { Support for bridge deck } \\
\text { during replacement }\end{array}$ & $50-100$ & 3300 \\
\hline
\end{tabular}

the spillway dam. To make an optimization of the repair technique, the different options are summarized with pros and cons, costs and service life in Table 3.

With all the facts from assessments and suggested technical solutions a common workshop between SWECO and ZESCO gave a platform for ZESCO to take a decision after internal counsel. Alternative A1 was found to be the most attractive alternative to resolve the issues with the spillway dam since other combinations of methods contain larger uncertainties and higher cost without substantially longer service-life and with higher risks during construction.

\section{DESIGN AND CONSTRUCTION}

After selection of technical solution for repair in cooperation with ZESCO a detailed design was performed including calculations and production of drawings and tender documents for procurement. A sketch showing the principle for installation of post tensioned anchors in the piers is shown in Figure 12. Selected type of tendon is the VSL 6-7 type with an applied force of $1300 \mathrm{kN}$ each. Tender documents were prepared according to FIDIC Red book and the construction works are planned during the spring 2019.
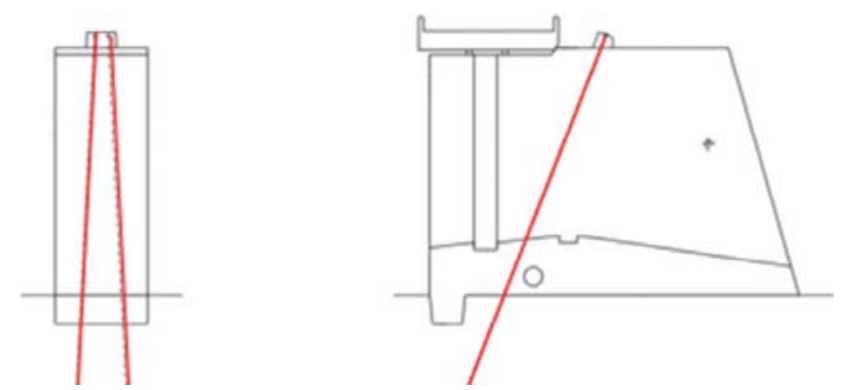

Figure 12. Principle for installation of stabilizing post-tensioned anchors in piers. 


\section{REFERENCES}

CONTECVET (2001). A validated user's manual for assessing the residual service life of concrete structures. EC Innovation Program. No. IN309021.

EN 12390-6:2009. (2009). Testing hardened concrete - Part 6: Tensile splitting strength of test specimens. CEN.

EN 12504-1:2009. (2009). Testing concrete in structures - Part 1: Cored specimens - Taking, examining and testing in compression. CEN.

Fossgaard, R. (2014). Personal communication regarding construction period of Kafue Gorge.

Hartford, D., Poupart, M. \& Zielinski, A. (2017). Dam safety management: Operational phase of the dam life cycle. ICOLD bulletin no 154.

Nordström, E., Rosenqvist, M., Sjödin, G., Hautakoski, M. (2013). Field investigations on the risk for ASR when using potentially reactive aggregates and low alkali cements. Results after 50 years in Sweden. Proceedings from ICOLD annual meeting. Seattle, USA.

NORDTEST (1985). Alkali-silica reactivity accelerated test. Test method NT Build 295

Penche, C. (2004). Guide on how to develop a small hydropower plant. ESHA.

Raphael, J.M. (1984). Tensile strength of concrete. ACI Journal proc., V.81, no 2, pp 158-165.

REHABCON (2004). Strategy for maintenance and rehabilitation in concrete structures. EC DG ENTRC-2. Innovation and SME Program. No. IPS-2000-0063.

RILEM (2003). Recommended test method AAR-1: Detection of potential alkali-reactivity of aggregates - Petrographic method.

SS-EN 137003:2015 (2015). Concrete - Application of SS-EN 206 in Sweden. Swedish Standard Institute (in Swedish) 